\title{
AUDIT
}

\section{UK Audit of Childhood Growth Hormone Prescription, 1998}

\author{
J Hilken, for the British Society for Paediatric Endocrinology and Diabetes Clinical \\ Trials/Audit Group
}

\begin{abstract}
Aims-To identify all young people prescribed growth hormone in the UK as of 1 October 1998 and to determine their age, sex, and the indication for therapy.

Methods-Cross sectional national postal audit through members of the British Society for Paediatric Endocrinology and Diabetes (BSPED) and other paediatricians identified as potential prescribers of growth hormone. Main outcome measures were age, sex, and numbers of children receiving growth hormone by diagnostic category, analysed throughout the UK and by NHS region.

Results-A total of 3228 children (aged 0.3
\end{abstract} to 23.9 years) receiving growth hormone were identified by contacting 171 paediatricians (149 BSPED members). Of these, 2395 (74\%) were identified who were under 16 years-representing 19.8/100 000 children in that age range in the UK-and in whom full data concerning diagnostic category were available. In the under $16 \mathrm{~s}$, there were $1209(50.4 \%)$ boys and 1186 (49.6\%) girls (excluding the 477 girls with Turner's syndrome: $63 \%$ boys and $37 \%$ girls). A total of $78 \%$ of the prescriptions were for licensed indications (primary and secondary growth hormone deficiency, Turner's syndrome, and chronic renal disease); $22 \%$ were for unlicensed indications (intrauterine growth restriction, bony dysplasia, Noonan syndrome, and other "short normals"). These proportions are similar to those reported in previous audits and by postmarketing surveillance from Pharmacia \& Upjohn Ltd in the year 2000. Patterns of treatment were relatively uniform between regions.

Conclusions-A national audit of UK growth hormone prescription indicates uniform prescribing practice between regions, low levels of prescription beyond licensed indications, and stable patterns of prescribing practice over the past two years.

(Arch Dis Child 2001;84:387-389)

Ms Hilken

jeh48@cam.ac.uk

Accepted 21 February 2001
Growth hormone has been available for the treatment of short stature since the early 1960s. ${ }^{1}$ Early growth hormone preparations were derived from human pituitary extracts, but this source was withdrawn in 1985 following early reports of possible association with the subsequent development of CreutzfeldtJakob disease. ${ }^{2}$ However, within 12 months biosynthetic human growth hormone became available and unlike the product derived from the pituitary extract, natural sequence $E$ coli derived human growth hormone was available in unlimited quantities. ${ }^{3}$ Currently, growth hormone therapy has been recommended for a number of licensed indications including growth hormone insufficiency, Turner's syndrome, growth failure associated with chronic renal disease, and most recently, for the growth hormone deficiency associated with PraderWilli syndrome.

Prior to 1985, a national committee, the Health Services Human Growth Hormone Committee, funded by the NHS, approved all growth hormone prescriptions in the UK. The committee reviewed the clinical history, indications for treatment, and arranged supplies of growth hormone derived from pituitary extracts. ${ }^{4}$ With the advent of human biosynthetic growth hormone, this committee was disbanded and the responsibility for prescription was devolved to the individual growth centres and local paediatricians. Under the internal market arrangements introduced into the NHS, the cost of the prescription was further devolved to the general practitioners, who collaborate in shared care arrangements with local paediatricians.

A consequence of these rearrangements in the method of growth hormone prescription was that there was no longer a central database, and regular audit of growth hormone prescription has proved difficult. The membership of the British Society for Paediatric Endocrinology and Diabetes (BSPED) includes all the paediatric endocrinologists in the UK; they carry the largest responsibility for growth hormone prescription. In 1998, the Society agreed that as a prelude to future longitudinal audit of growth hormone prescription, the Society would endeavour to determine how many children were on growth hormone as of 1 October 1998, and the indications for therapy. 
Table 1 Numbers and indications for growth hormone (GH) therapy

\begin{tabular}{|c|c|c|c|c|c|}
\hline Code & Diagnosis & Total no. $R_{x}$ & $\%$ males & Age range (median) & $\begin{array}{l}\text { \% of total } \\
G H R_{x}\end{array}$ \\
\hline & $\begin{array}{l}\text { Licensed indications (78\%) } \\
\text { GH deficiency }(55 \%)\end{array}$ & & & & \\
\hline 1 & Idiopathic growth hormone deficiency & 656 & $68 \%$ & $0.3-15.9(11.5)$ & $27 \%$ \\
\hline 2 & Congenital growth hormone deficiency (e.g. septo-optic dysplasia) & 225 & $61 \%$ & $0.7-15.9(8.4)$ & $9 \%$ \\
\hline 3 & Craniopharyngioma & 91 & $58 \%$ & $2.8-15.9(12.2)$ & $4 \%$ \\
\hline 4 & Other acquired growth hormone deficiency (e.g. post-irradiation) & 347 & $57 \%$ & $0.5-15.9(12.5)$ & $14 \%$ \\
\hline 5 & Turner syndrome & 477 & $0 \%$ & $2.4-15.9(11.3)$ & $20 \%$ \\
\hline 6 & $\begin{array}{l}\text { Renal disease } \\
\text { Unlicensed indications (22\%) }\end{array}$ & 63 & $68 \%$ & $3.0-15.9(10.3)$ & $3 \%$ \\
\hline 7 & Intrauterine growth retardation & 74 & $67 \%$ & $2.3-15.6(10.7)$ & $3 \%$ \\
\hline 8 & Noonan syndrome & 44 & $68 \%$ & $7.0-15.9(12.2)$ & $2 \%$ \\
\hline 9 & Bony dysplasia & 107 & $55 \%$ & $2.7-15.8(11.5)$ & $4 \%$ \\
\hline 10 & All others & 311 & $61 \%$ & $0.5-15.9(11.9)$ & $13 \%$ \\
\hline Total & & 2395 & & & $100 \%$ \\
\hline
\end{tabular}

\section{Subjects and methods}

In 1998, all clinical members of the BSPED $(n=149)$ in the UK were contacted and asked to provide details of patients on growth hormone therapy as of 1 October 1998; 39 BSPED members reported prescribing growth hormone. For simplicity, the diagnostic criteria were grouped into the categories shown in table 1. BSPED members were also asked to identify any other doctors not in the BSPED who might be prescribing growth hormone within their region. Twenty two further prescribers were identified; they were also contacted for similar details of growth hormone prescription.

ANALYSIS

Numbers and details of prescription were analysed nationally and by NHS region. These were the regions current on 1 October 1998 (Anglia \& Oxford, North West, Northern \& Yorkshire, Northern Ireland, Scotland, North \& South Thames, South West, Trent, Wales, West Midlands). In order to estimate the numbers of children under the age of 16 years being treated for individual indications within these regions, population data were obtained from the Office of National Statistics (ONS), established from census data collected in 1997.5

\section{Results}

The BSPED membership reported a total of 2434 prescriptions, and the 18 non-members of the society reported an additional 794 prescriptions, giving a total of 3228. The age range of the children being treated at the time of audit was 0.3 to 23.9 years (median 12.2). There were 53\% males (age range 0.5-23.9 years, median 12.6), and $47 \%$ females (age range 0.3-21.1 years, median 11.8).

Because of variable ascertainment of subjects aged 16 years or over, relating to referral to adult clinics, subsequent analysis was confined to those aged under 16 years. A total of 2395 subjects were thus identified, representing 19.8/100 000 children aged under 16 years in the UK, in whom full details of the diagnosis were available. There were 1209 (50.4\%) boys and 1186 (49.6\%) girls; excluding the 477 Turner girls changed the balance to $63 \%$ boys and $37 \%$ girls.

Table 1 summarises the indications for growth hormone therapy in these 2395 children. Overall, $78 \%$ of prescriptions were for licensed indications, including growth hormone deficiency (idiopathic, congenital, secondary (craniopharyngioma and other acquired), Turner's syndrome, and renal disease); $22 \%$ of prescriptions were for other indications. The numbers and ages of children receiving growth hormone for the various indi-

Table 2 Comparison of numbers in treatment for different indications in the UK regions

\begin{tabular}{|c|c|c|c|c|c|c|c|c|c|c|}
\hline \multirow[b]{2}{*}{ Region } & \multirow[b]{2}{*}{$\begin{array}{l}\text { Population aged } \\
<16 y\end{array}$} & \multicolumn{3}{|c|}{ GHD (code 1-4) } & \multicolumn{3}{|c|}{ Turner (code 5) } & \multicolumn{3}{|c|}{ Unlicensed (code 7-10) } \\
\hline & & $\begin{array}{l}\text { No. } \\
\text { reported }\end{array}$ & $\begin{array}{l}\text { per } \\
100000\end{array}$ & $\begin{array}{l}\text { Age range } \\
\text { (median) }\end{array}$ & $\begin{array}{l}\text { No. } \\
\text { reported }\end{array}$ & $\begin{array}{l}\text { per } \\
100000\end{array}$ & $\begin{array}{l}\text { Age range } \\
\text { (median) }\end{array}$ & $\begin{array}{l}\text { No. } \\
\text { reported }\end{array}$ & $\begin{array}{l}\text { per } \\
100000\end{array}$ & $\begin{array}{l}\text { Age range } \\
\text { (median) }\end{array}$ \\
\hline Anglia \& Oxford & 1119870 & 107 & 9.6 & $\begin{array}{l}0.5-15.6 \\
(11.1)\end{array}$ & 40 & 3.6 & $\begin{array}{l}3.5-15.9 \\
(10.9)\end{array}$ & 48 & 4.3 & $\begin{array}{l}4.0-15.7 \\
(12.9)\end{array}$ \\
\hline $\begin{array}{l}\text { North \& South } \\
\text { Thames }\end{array}$ & 2812660 & 242 & 8.6 & $\begin{array}{l}4.0-15.9 \\
(12.2)\end{array}$ & 50 & 1.8 & $\begin{array}{l}4.0-15.3 \\
(12.0)\end{array}$ & 91 & 3.2 & $\begin{array}{l}2.7-15.8 \\
(11.0)\end{array}$ \\
\hline North West & 1398780 & 154 & 11.1 & $\begin{array}{l}0.3-15.9 \\
(10.4)\end{array}$ & 78 & 5.6 & $\begin{array}{l}4.7-15.8 \\
(12.6)\end{array}$ & 55 & 3.9 & $\begin{array}{l}3.1-15.8 \\
(11.9)\end{array}$ \\
\hline N \& Yorkshire & 1298880 & 178 & 13.7 & $\begin{array}{l}1.1-15.9 \\
(10.6)\end{array}$ & 46 & 3.5 & $\begin{array}{l}2.7-14.9 \\
(9.8)\end{array}$ & 46 & 3.5 & $\begin{array}{l}2.7-15.6 \\
(12.1)\end{array}$ \\
\hline Northern Ireland & 412000 & 51 & 12.4 & $\begin{array}{l}7.0-15.7 \\
(11.7)\end{array}$ & 26 & 6.3 & $\begin{array}{l}6.2-15.6 \\
(12.0)\end{array}$ & 25 & 6.1 & $\begin{array}{l}3.1-15.3 \\
(12.0)\end{array}$ \\
\hline Scotland & 1019480 & 118 & 11.6 & $\begin{array}{l}5.0-15.9 \\
(12.4)\end{array}$ & 60 & 5.9 & $\begin{array}{l}4.0-15.5 \\
(11.7)\end{array}$ & 73 & 7.2 & $\begin{array}{l}2.0-15.6 \\
(11.0)\end{array}$ \\
\hline South West & 1294610 & 106 & 8.2 & $\begin{array}{l}3.0-15.7 \\
(11.2)\end{array}$ & 44 & 3.4 & $\begin{array}{l}4.0-15.9 \\
(10.6)\end{array}$ & 32 & 2.5 & $\begin{array}{l}2.0-15.3 \\
(11.2)\end{array}$ \\
\hline Trent & 1035860 & 105 & 10.1 & $\begin{array}{l}1.3-15.9 \\
(11.0)\end{array}$ & 41 & 4.0 & $\begin{array}{l}2.4-15.0 \\
(9.0)\end{array}$ & 21 & 2.0 & $\begin{array}{l}0.5-15.2 \\
(13.0)\end{array}$ \\
\hline Wales & 600000 & 65 & 10.8 & $\begin{array}{l}3.4-15.7 \\
(11.7)\end{array}$ & 19 & 3.2 & $\begin{array}{l}2.9-15.2 \\
(12.4)\end{array}$ & 19 & 3.3 & $\begin{array}{l}6.7-14.1 \\
(11.8)\end{array}$ \\
\hline West Midlands & 1117410 & 193 & 17.3 & $\begin{array}{l}1.6-15.7 \\
(11.8)\end{array}$ & 73 & 6.5 & $\begin{array}{l}2.8-15.5 \\
(11.3)\end{array}$ & 126 & 11.3 & $\begin{array}{l}2.2-15.9 \\
(12.1)\end{array}$ \\
\hline
\end{tabular}

GHD, growth hormone deficiency. 
cations were relatively uniform between the regions (table 2 ).

\section{Discussion}

With the abolition of the Health Services Human Growth Hormone Committee in 1985, it has been difficult to assess the numbers and therapeutic rationale for growth hormone prescription in the UK. Whereas licensed indications for growth hormone have been extended from "straightforward" growth hormone deficiency to children with Turner's syndrome, chronic renal disease, and most recently Prader-Willi syndrome, the implication in relation to cost/benefit has been difficult to establish. The benefits of growth hormone treatment in some of these conditions have been debated and the use of growth hormone outside licensed indications has not been determined.

In 1998, the BSPED undertook this audit to establish prescribing practice in the UK. A total of 57 paediatricians prescribing growth hormone were identified, of which the majority, 39, were BSPED members. Many of these were directors of the original regional registers of growth hormone prescribers or their natural successors. Response rates to the audit were satisfactory $(70 \%$ of consultants contacted provided full details of growth hormone prescriptions). Limitations of the audit might include a failure to identify all paediatricians and adult physicians prescribing growth hormone to children, particularly those prescribing within the private sector. It is also likely that some nephrologists initiating growth hormone therapy in patients with chronic renal disease were not identified.

Nevertheless, the number of children under 16 receiving growth hormone within the UK (2395) is a reasonable estimate, representing $19.8 / 100000$ children. The majority of children were being treated for licensed indications, whereas the remaining $22 \%$ were being treated for unlicensed indications. An audit of growth hormone therapy in Scotland completed in 1999 indicated that $20 \%$ of children were being treated outside of licensed indications. ${ }^{6}$ Postmarketing surveillance surveys carried out by Pharmacia \& Upjohn Ltd reported $21 \%$ being treated outside licensed indications in $1994^{7}$; more recently in 2000 , in a survey of 2163 children, growth hormone deficiency, Turner's syndrome, and other licensed indications accounted for $77 \%$ of prescriptions, the remaining $23 \%$ being for unlicensed indications.

The number of children receiving growth hormone for growth hormone deficiency (approximately 1/7334) is lower than that reported previously by the MRC working party in 1979 and the Utah growth study in $1994,{ }^{4}{ }^{8}$ even though the numbers of children developing growth hormone insufficiency following cranial radiotherapy or other oncological therapies have increased through the years. It is unlikely that "missed patients" could completely account for this discrepancy, as not all would be growth hormone deficient. Rather, it supports the clinical impression that the prevalence of growth hormone deficiency may be declining. The cause of this decline is not known but could partly relate to increasing rates of surgical delivery in infants with breech presentation. ${ }^{9}$

Regional analysis of prescribing practice was reassuring, in that the percentages of growth hormone prescriptions for the different indications were similar. Some anomalies were inevitable as referral practices are complex. For example, low rates of ascertainment in Wales reflected referral practice whereby short children from North Wales were referred to Liverpool, and the low number of children with craniopharyngioma reflected uneven referral to regional centres, particularly in London.

Overall these data indicate relatively uniform prescribing practice throughout the UK, low levels of prescription beyond licensed indications, and stable patterns of prescribing practice over the past two years.

The membership of the British Society for Paediatric Endocrinology and Diabetes Clinical Trials/Audit Group comprises: T Cole, MDC Donaldson, DB Dunger (Chair), PC Hindmarsh, CJH Kelnar, and M Preece.

We would like to thank all members of the BSPED and other paediatricians from the RCPCH who provided us with details of
growth hormone prescriptions. We would also like to thank growth hormone prescriptions. We would also like to thank
Pharmacia \& Upjohn for their assistance in collecting some of the data through the KIGS database.

1 Raben MS. Treatment of a pituitary dwarf with human growth hormone. F Clin Endocrinol 1958;18:901-3.

2 Brown P, Preece MA, Will RG. "Friendly fire" in medicine: hormones, homografts, and Creutzfeldt-Jakob disease. Lancet 1992;340:24-7.

3 Flodh H. Human growth hormone produced with recombinant DNA technology: development and production. Acta Paediatr Scand Suppl 1986;325:1-9.

4 Milner RDG, Russell Fraser T, Brook CGD, et al. Experience with human growth hormone in Great Britain: the report of the MRC Working Party. Clin Endocrinol the report of the

5 Office of National Statistics, Population and Vital Statistics. NHS Regional Office Areas, 1997: Regional Trends Dataset. Adapted for StatBase from Regional Trends 1999;34.

6 Patterson WF, Donaldson MDC, Greene SA, et al. The boom that never was: results of a 10 year audit of paediatric growth hormone in Scotland. Health Bull 2000;60:457-66.

7 Price DA, Johnston DI, Betts PR, et al. Biosynthetic human growth hormone treatment in the UK: an audit of current practice. Arch Dis Child 1994;71:266-71.

8 Lindsay R, Feldkamp M, Harris D, et al. Utah Growth Study: growth standards and the prevalence of growth hormone deficiency. $\mathcal{F}$ Pediatr 1994;125:29-35.

9 Herber SM, Milner RD. When are we diagnosing growth hormone deficiency? Arch Dis Child 1986;61:110-12. 